\title{
Архитектор П.И. Гольденберг и его вклад в формирование принципов архитектурно-пространственной организации жилого квартала в СССР в 1930-е годы
}

\author{
Ю.Д.Старостенко, НИИТИАГ, Москва
}

Статья посвящена воссозданию биографии и творческого пути архитектора Петра Исааковича Гольденберга (1902-1971), имя которого сегодня практически забыто несмотря на то, что многие его научные работы активно используются как историками архитектуры, так и специалистами по истории развития Москвы. Личные документы П.И. Гольденберга и его рукописи, сохранившиеся в фонде архитектора в Российском государственном архиве экономики, позволили восстановить ключевые даты его жизни и творчества в рассматриваемый период, а также определить круг вопросов, изучением которых занимался архитектор, выбравший в силу обстоятельств главной сферой своих интересов научную деятельность. В центре внимания статьи находятся публикации П.И. Гольденберга, а также различные материалы из его архива, связанные с формированием принципов архитектурно-пространственной организации жилого квартала в СССР в 1930-е годы. Исследования в этой области были начаты архитектором по заказу Планировочно-земельного отдела Моссовета в 1931 году и впоследствии практически без перерыва продолжались вплоть до начала Великой отечественной войны, независимо от изменения мест работы исследователя - в Архитектурно-планировочном управлении Моссовета, в Академии коммунального хозяйства, в Отделе планировки Моссовета, в Академии архитектуры. И хотя П.И. Гольденберг был не единственным специалистом в этой области в СССР, его публикации выходили на протяжении всего десятилетия и позволяют проследить, как менялись представления о принципах архитектурно-пространственной организации жилого квартала и с какими проблемами сталкивались архитекторы при разработке проектов застройки жилых кварталов в течение $1930-x$ годов $^{1}$.

Ключевые слова: П.И. Гольденберг, жилой квартал, архитектурно-пространственная организация жилого квартала, строчная застройка, периметральная застройка, советское градостроительство, 1930-е.

Architect P.I. Goldenberg and His Contribution to the Formation of the Principles of Architectural and Spatial Organization of a Residential Quarter in the USSR in the 1930s Yu.D.Starostenko, NIITIAG, Moscow

The article is devoted to recreating the biography and creative path of the architect Peter Isaakovich Goldenberg (1902-1971).

${ }^{1}$ Исследование выполнено за счёт средств Государственной программы Российской Федерации «Развитие науки и технологий» на 2013-2020 годы в рамках Плана фундаментальных научных исследований Минстроя России и РАAСН. Тема 1.2.19.
His name is almost forgotten today due to various circumstances, despite the fact that many of his scientific works were actively used by both architectural historians and specialists in the history of Moscow's development. P.I. Goldenberg's personal documents and manuscripts, preserved in the architect's Fund in the Russian state archive of Economics, allowed to restore the key dates of his life and work in the review period. They also helped determine the range of issues that were studied by the architect, who, due to circumstances, chose scientific activity as the main sphere of his interests. This article focuses on the publications of P.I. Goldenberg, as well as various materials deposited in his archive and related to the formation of the principles of the architectural and spatial organization of a residential quarter in the USSR in the 1930s. The architect began research in this area by order of the Planning and land Department of the Moscow Soviet in 1931, and subsequently almost without interruption, continued until 1941, despite the change of jobs - in the Architectural and Planning Department of the Moscow Soviet, the Academy of public utilities, Department of planning of the Moscow Soviet, the Academy of architecture. And although P.I. Goldenberg was not the only specialist in this field in the USSR, his publications were published throughout the decade, and allow us to trace how ideas about the principles of the architectural and spatial organization of a residential quarter changed, and what problems architects faced when developing residential development projects during the 1930s.

Keywords: P.I. Goldenberg, residential quarter, architectural and spatial organization of a residential quarter, line building, ribbon building, Soviet town planning, 1930s.

Имя архитектора Петра Исааковича Гольденберга (рис. 1) сегодня практически забыто несмотря на то, что его книги и статьи лежат в основе многих исследований как по истории советской архитектуры, так и по истории развития Москвы. Среди них книги «Архитектура жилого квартала Москвы XVII, XVIII и XIX вв.» (совместно с Б.И. Гольденбергом) и «Набережные Москвы» (совместно с Аксельродом); статья, посвящённая проекту развития Москвы, выполненному в конце 1930 года под руководством В.Н. Семёнова, статья с анализом проектов перепланировки Москвы и многие другие. Между тем П.И. Гольденберг - один из немногих советских архитекторов, работавших и активно публиковавшихся в 1930-е годы, кто не просто сохранил свой рабочий архив, но и передал его на хранение в Центральный государственный архив народного хозяйства (ЦГАНХ) СССР - ныне Российский государственный 
архив экономики (РГАЭ). Фонд П.И. Гольденберг в РГАЭ является уникальным по своей полноте собранием документов, связанных с жизнью и творчеством архитектора. И целью настоящей статьи, подготовленной на основе этих материалов, является не только воссоздание биографии П.И. Гольденберга, но и анализ его вклада в развитие советского градостроительства 1930-х годов, в частности, в разработку проблемы жилого квартала, которой архитектор активно занимался в это время.

П.И. Гольденберг родился в Симферополе 3 января 1902 года² . Отец Петра Исааковича - Исаак-Израиль Абрамов-Шлемов Гольденберг ${ }^{3}$ - окончил юридический факультет Харьковского университета, но работал учителем. «В 1905 году 18 октября он был убит на бульваре в Симферополе во время разгрома черносотенцами революционной демонстрации, окончившейся еврейским погромом»4. Мать - Аахиль-Леа или Розалия Львовна - также работала учительницей и после гибели мужа одна воспитывала сыновей - старшего Петра и родившегося годом позднее Бориса.

С 1911 года П.И. Гольденберг учился в восьмиклассном Коммерческом училище Симферопольского купеческого общества, которое окончил 1 июня 1920 года с золотой медалью5 . В том же году он поступил на историко-филологический факультет Таврического университета, в котором проучился до конца весеннего семестра 1923 года (окончил при этом только два курса). Поскольку в училище П.И. Гольденберг среди прочих предметов освоил рисунок и черчение, он смог в конце декабря 1921 года устроиться чертёжником в Статистический отдел
Крымского Совета профессиональных союзов, где проработал до 1 августа 1923 года 6 . Именно тогда он был командирован для учёбы в Москву, где поступил на архитектурный факультет Высших художественных мастерских (ВХУТЕМАС). Его он окончил в 1928-1929 учебном году, «несмотря, - как отмечал сам Пётр Исаакович, - на тяжёлое заболевание» (рис. 2).

Однако ещё до завершения учебы, 20 июня 1928 года, П.И. Гольденберг начал работать в Планировочно-земельном отделе Московского коммунального хозяйства (МКХ). Согласно записям архитектора, сначала он был занят на оперативной работе по планировке Москвы как районный инженер Пролетарского района, а «потом научно-исследовательской работой - разрешая выдвигавшиеся жизнью вопросы». Он продолжал работать в отделе, несмотря на ряд его последовательных реорганизаций, вплоть до конца 1932 года. За это время в связи с ликвидацией МКХ Планировочно-земельный отдел в марте 1931 года перешёл в ведение Моссовета [1, с. 633], потом в феврале 1932 года вошёл в Архитектурно-планировочное управление (АПУ) Моссовета [1, с. 735]. И именно из АПУ П.И. Гольденберг был уволен 28 декабря 1932 года «по сокращению штатов»7.

В следующие два года - с 1 января 1933 года по 25 ноября 1934-го П.И. Гольденберг работал старшим научным сотрудником в Секторе планировки Академии коммунального хозяйства $\left(\mathrm{AKX)} \mathrm{в}\right.$ Москве $^{8}$. Из АКХ он ушёл по собственному желанию, чтобы вернуться в Отдел планировки Моссовета - один из трёх отделов, сформированных в сентябре 1933 года вместо АПУ

\footnotetext{
${ }^{2}$ [Копия выписки из метрической книги с записью о рождении П.И. Гольденберга] (источник: РГАЭ. Ф. 185. 0п. 1. Д. 226. Л. 27).

${ }^{3}$ Имя приводится по записи в метрической книге о рождении П.И. Гольденберга. Иных вариантов написания обнаружить не удалось.

${ }^{4}$ Гольденберг П. Автобиография. 15 января 1937 г. [Дополнялась после 1942 г.] (источник: РГАЭ. Ф. 185. Оп. 1. Д. 226. Л. 8).

${ }^{5}$ Копия с копии аттестата П.И. Гольденберга (источник: РГАЭ. Ф. 185. 0п. 1. Д. 226. Л. 23-24).

${ }_{6}^{6}$ Удостоверение от Крымского Совета Профессиональных союзов от 27 июля 1923 г. (источник: РГАЭ. Ф. 185. Оп. 1. Д. 226. Л. 79).

${ }^{7}$ Справка Архитектурно-планировочного управления Моссовета о работе П.И. Гольденберга от 27 декабря 1932 г. (источник: РГАЭ. Ф. 185. Оп. 1. Д. 226. Л. 78).

8 Личный листок П.И. Гольденберга по учёту кадров Института градостроительства Академии архитектуры СССР от 7 сентября 1947 г. (источник: РГАЭ. Ф. 185. 0п. 1. Д. 226. Л. 18 об.); Справка из Государственной академии коммунального хозяйства при СНК РСФСР от 3 декабря 1934 г. (источник: РГАЭ. Ф. 185. Оп. 1. Д. 226. Л. 80).
}

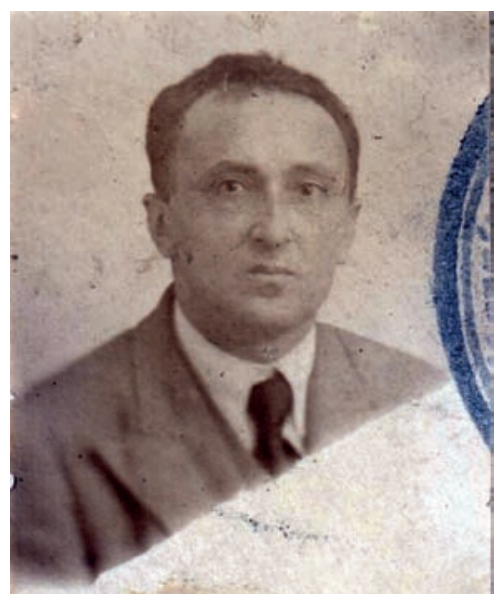

Рис. 1. Фотография П.И. Гольденбергасчленского билета Профсоюзаработников высшей школы и научных учреждений. 1938 год (источник: РГАЭ. Ф. 185. Oก. 1. Д. 228. Л. 2)

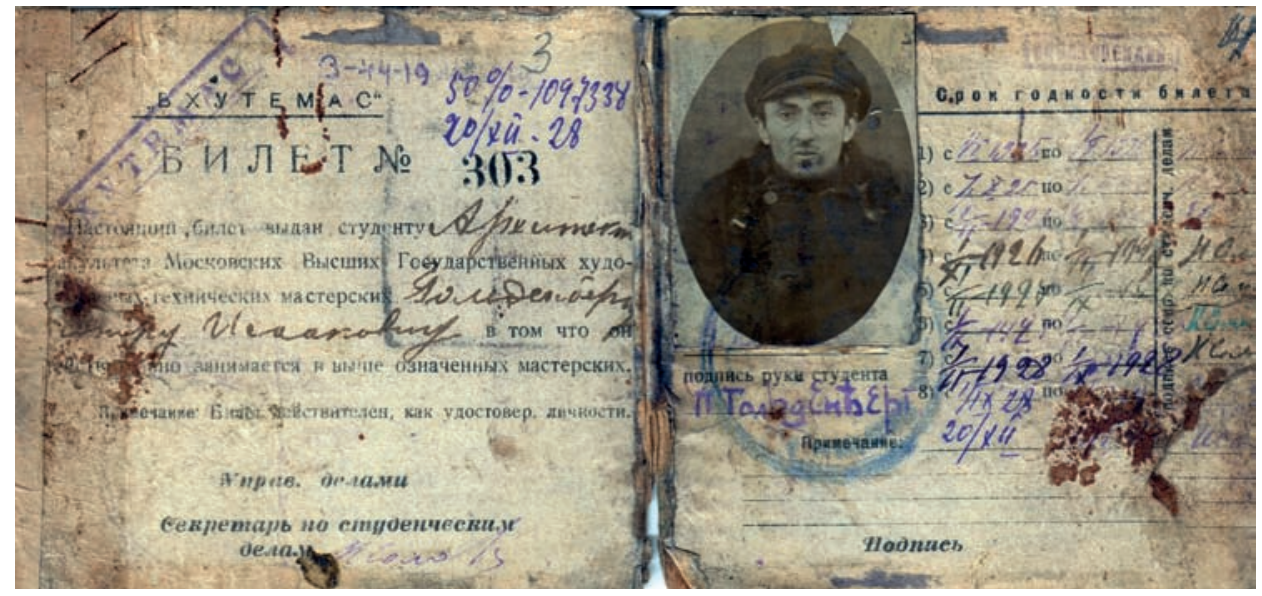

Рис. 2. Студенческий билет П.И. Гольденберга. ВХУТЕМАС. 1925 год (?) (источник: РГАЭ. Ф. 185. Oп. 1. Д. 228. Л. 3-4) 
[1, с. 645]. Там он проработал до 29 апреля 1936 года, когда по решению врачебно-трудовой экспертной комиссии получил временную инвалидность. Болезнь П.И. Гольденберга была спровоцирована смертью от туберкулёза его брата Бориса осенью 1935 года и последовавшим за этим помешательством их матери ${ }^{9}$. Лишь через полгода, 7 октября 1936 года, П.И. Гольденберг смог вернуться к работе, но уже в качестве старшего научного сотрудника Кабинета планировки и садово-парковой архитектуры (с января 1937 года - Кабинет градостроительства) Всесоюзной академии архитектуры, где и проработал до 28 апреля 1939 года. Вновь полученная временная инвалидность не позволяла П.И. Гольденбергу работать в полную силу, но он продолжал работу в академии на договорных началах вплоть до января 1942 года, когда вернулся на прежнюю должность старшего научного сотрудника уже в Институт градостроительства Академии архитектуры СССР ${ }^{10}$.

Таковы сухие данные, приводившиеся П.Г. Гольденбергом в его автобиографии и подтверждающиеся различными личными листками и другими документами архитектора. Однако будучи крайне важными для понимания его творческого пути, они мало что могут рассказать о П.И. Гольденберге как архитекторе и исследователе.

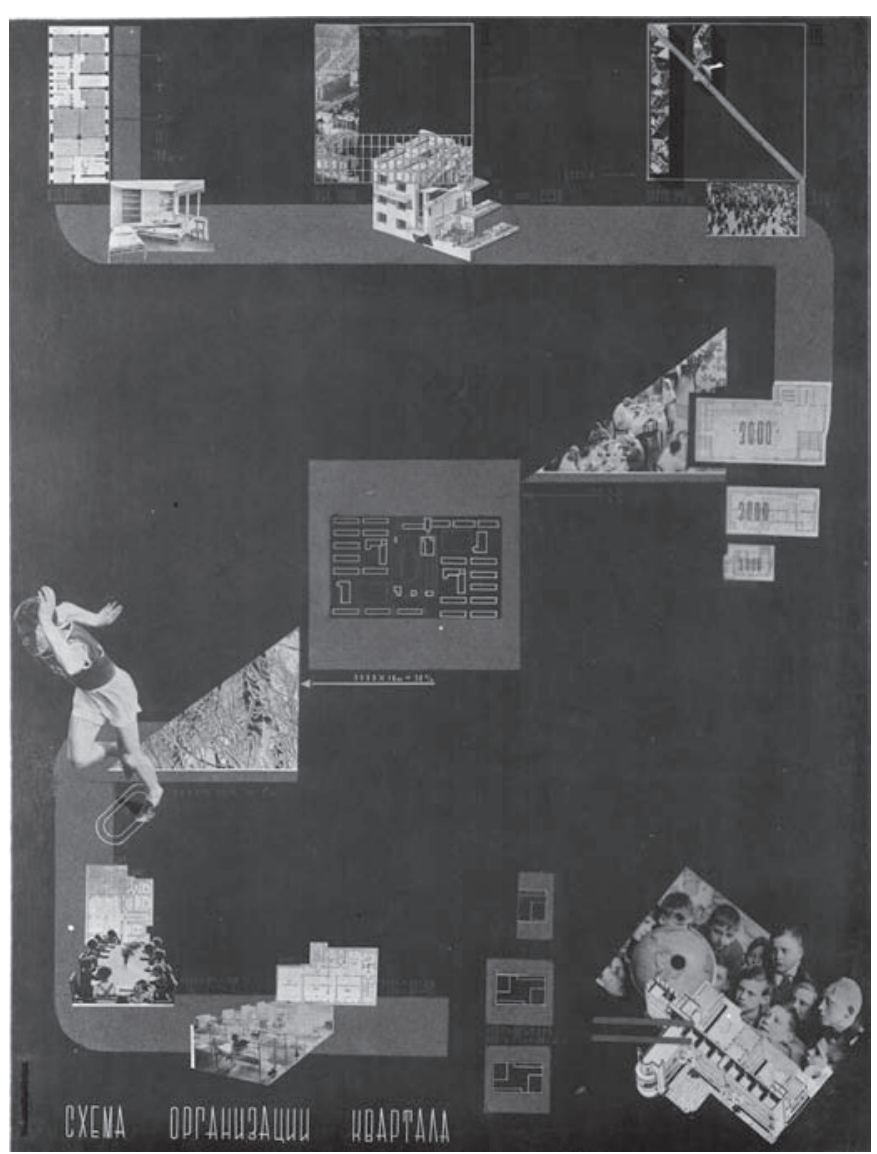

Рис. 3. Схема организации квартала (для книги «Проблемы жилого квартала»). 1931 год (источник: РГАЭ. Ф. 185. On. 1. Д. З. Ч. 2. Л. 147).
Первой его заметной работой, которая в равной степени была связана с обоими направлениями деятельности архитектора, стало участие в разработке проекта планировки Москвы, который был выполнен в Планировочно-земельном отделе Моссовета под руководством В.Н. Семёнова в ноябре 1930 года. Статья, в которой излагались принципы, лежавшие в основе этого проекта, была опубликована во второй половине 1931 года от имени трёх молодых архитекторов - С.А. Болдырева, П.И. Гольденберга и В.И. Долганова [2]11. Авторы публикации особо оговаривали, что схема носит гипотетический характер, и в ней не получил разрешения целый ряд вопросов. По этой схеме социалистическая реконструкция столицы должна была заключаться «в расчленении исторически сложившегося городского пятна согласно сознательно осуществляемого плана на систему городовкомплексов, расположенных вокруг старого городского центра» [2, с. 33]. 0 принципах организации таких городов-комплексов, кроме того, что каждый из них будет обладать «значительной долей самостоятельности» и будет «погружён» в защитную зелёную зону, в статье более ничего не сообщалось.

В том же 1931 году П.И. Гольденбергом и В.И. Долгановым были опубликованы две статьи - «Капитальное или облегчённое стандартное строительство» [3], «Жилой комбинат» [4] - и книга «Проблема жилого квартала» [5] ${ }^{12}$, которые свидетельствовали о том, что разработка проекта планировки Москвы не остановилась на уровне концептуальной схемы. В центре внимания исследования, результаты которого были представлены в этих публикациях, была выработка принципов проектирования жилой застройки Москвы. Как сообщалось в книге, работа была выполнена по заданию заведующего Планировочно-земельным отделом В.Л. Орлеанского архитекторами П.И. Гольденбергом и В.И. Долгановым под руководством В.Н. Семёнова, причём среди участников проектировочной группы назывались Ф.И. Матвеев, Р.Л. Гольденберг, В.М. Зайцев, а также экономист Б.И. Гольденберг.

В этом исследовании социалистический жилой «кварталкомбинат» рассматривался как ключевая планировочная единица будущей Москвы (рис. 3). Его определяющими признаками были «коллективный быт и плановость построения» на базе гигиенических требований и экономической целесообразности. Авторы декларировали необходимость эволюции планировки от «замкнутых кварталов к поточным кварталам - органической части жилого района»; стремление к максимальному приближению и даже внедрению общественных сооружений в жилые дома; а также желательность перехода от «горизонтальной распластанности жилых зданий» к вертикальному построению с целью освобождения площади «для

\footnotetext{
${ }^{9}$ Гольденберг П. Автобиография. 15 января 1937 г. [Дополнялась после 1942 г.] (источник: РГАЭ. Ф. 185. 0п. 1. Д. 226. Л. 8).

10 Личный листок П.И. Гольденберга по учёту кадров Института градостроительства Академии архитектуры СССР от 7 сентября 1947 г. (источник: РГАЭ. Ф. 185. 0п. 1. Д. 226. Л. 18 об).

${ }^{11}$ Пояснительная записка к эскизной схеме перепланировки г. Москвы, выполненной Болдыревым, Гольденбергом, Долгановым под руководством проф. Семёнова в ноябре 1930 г. (источник: РГАЭ. Ф. 185. 0п. 1. Д. 105. Л. 2-7).

12 Подробнее о книге см.: [6].
} 
зелёных и воздушных резервуаров» [5, с. 76]. При этом в исследовании особо выделялись «центральное московское ядро» с плотностью населения в 500-600 чел/га, где предполагалась пяти- и шестиэтажная капитальная застройка (рис. 4), и «московская периферия», которая мыслилась «в виде широкого пояса двухэтажных стандартных домов с плотностью населения около 200 чел/га» [3] (рис. 5). Авторами также велись расчёты для двух вариантов обобществления быта - для «половинного обобществления» и для полного, - каждый из которых предполагал разное соотношение жилой и общественной площадей, а, следовательно, и иные планировочные решения кварталов.

Это исследование, близкое по ключевым положениям к дискуссии о социалистическом расселении рубежа 1920-х 1930-х годов, изданное в виде книги, стало одним из первых советских трудов, посвящённых проблеме проектирования жилого квартала. Однако его появление уже после сворачивания этой дискуссии было отнюдь не случайным. Постановление ЦК ВКП(б) «0 работе по перестройке быта» от 16 мая 1930 года, с одной стороны, поставило точку в дискуссии о соцрасселении, а с другой - сделало обязательным размещение в жилой застройке предприятий культурно-бытового обслуживания. И поскольку никакие нормы и принципы в постановлении не оговаривались, перед проектировщиками вставала задача поиска этих норм и принципов, которая и нашла отражение в работе, выполненной по заданию Планировочно-земельного отдела Моссовета. Её актуальность в 1931 году была подтверждена постановлением июньского Пленума ЦК ВКП(б) 1931 года «0 московском городском хозяйстве и о развитии городского хозяйства СССР», в котором не только говорилось о необходимости разработки «серьёзного, научнообоснованного плана дальнейшего расширения и застройки г. Москвы», но и акцентировалась задача обдуманного размещения предприятий культурно-бытового обслуживания в жилой застройке.

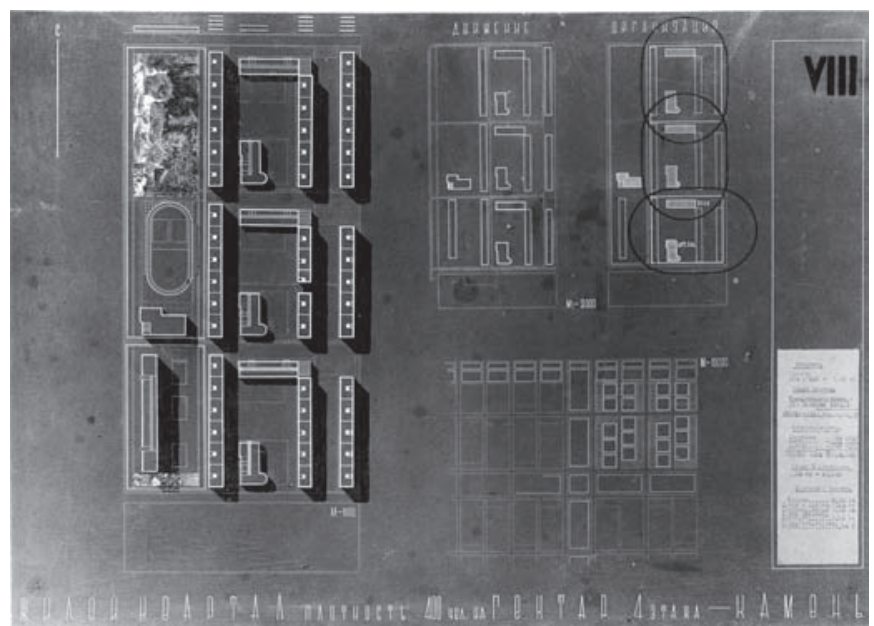

Pис. 4. Схема жилого квартала плотностью 400 чел/га с капитальной застройкой (для книги «Проблемы жилого квартала»). 1931 год (источник: РГАЭ. Ф. 185. On. 1. Д. 3. 4. 2. Л. 126).
С задачей разработки проекта планировки Москвы, хотя и в разной степени, были связаны две следующие работ П.И. Гольденберга. Первой из них был конкурсный проект планировки Центрального парка культуры и отдыха, выполненный П.И. Гольденбергом и В.И. Долгановым под эгидой Всесоюзного объединения пролетарских архитекторов (ВОПРА). И хотя, по мнению критики, проект не давал «исчерпывающего решения планировки парка», к его достоинствам были отнесены тщательный «социологический анализ систем парков в прошлом и настоящем» и стремление авторов поставить «схему планировки парка в непосредственную зависимость от новой планировки Москвы, дав принципы этой планировки [7, с. 50]. Второй работой стал анализ конкурсных схем планировки Москвы, разработанных в 1932 году. Результаты этого анализа в виде объёмного текста, подготовленного при участии брата Бориса, и схематических изображений конкурсных проектов, выполненных самим И.П. Гольденбергом, были опубликованы в журнале «Советская архитектура» [8]. Однако, несмотря на то, что результатами этой действительно значимой для молодого архитектора работы, активно пользовались его старшие коллеги - Б.А. Коршунов и В.Н. Семёнов ${ }^{13}$, П.И. Гольденберг был уволен из АПУ Моссовета в конце 1932 года.

Уже после увольнения архитектора вышла его статья «Строчная или периметральная застройка кварталов», написанная ещё в статусе сотрудника АПУ и фиксировавшая важный перелом в деле проектирования жилых кварталов, который произошел в 1932 году после провозглашения курса на магистральную застройку улиц и курса на «освоение культурного наследия». В статье речь шла уже о двух типах жилья для Москвы - комплексном и дифференцированном.

${ }^{13}$ Этот вопрос освещался в отдельной публикации, посвящённой конкурсу 1932 года [9]. Возможно, имел место конфликт между П.И. Гольденбергом и В.Н. Семёновым, во всяком случае, П.И. Гольденберг писал в своей автобиографии, что смог вернутся в Отдел планировки Моссовета в 1934 году «после падения проф. Семёнова» (источник: Гольденберг П. Автобиография. 15 января 1937 г. [Дополнялась после 1942 г.] - РГАЭ. Ф. 185. 0п. 1. Д. 226. Л. 8).

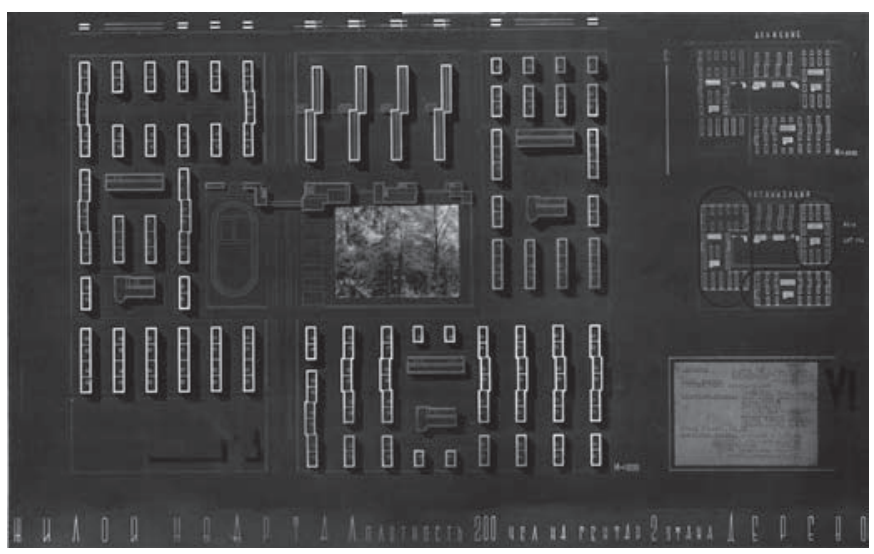

Рис. 5. Схема жилого квартала плотностью 200 чел/га с облегчённой стандартной застройкой (для книги «Проблемы жилого квартала»). 1931 год (источник: РГАЭ. Ф. 185. On. 1. Д. 3. Ч. 2. Л. 131). 


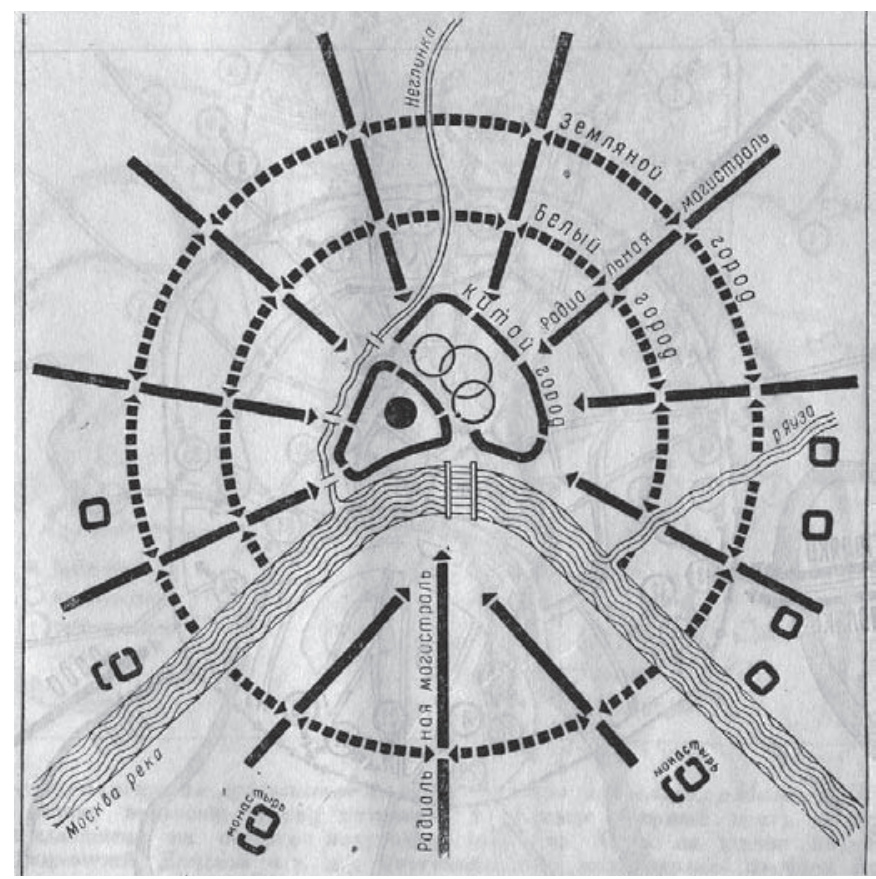

Рис. 6. Иллюстрация П.И. Гольденберга «Схематическое изображение московской планировочной системы XVII века» из книги «Планировка жилого квартала Москвы XVII, XVIII и XIX вв.». 1935 год (источник: [11, с. 26])

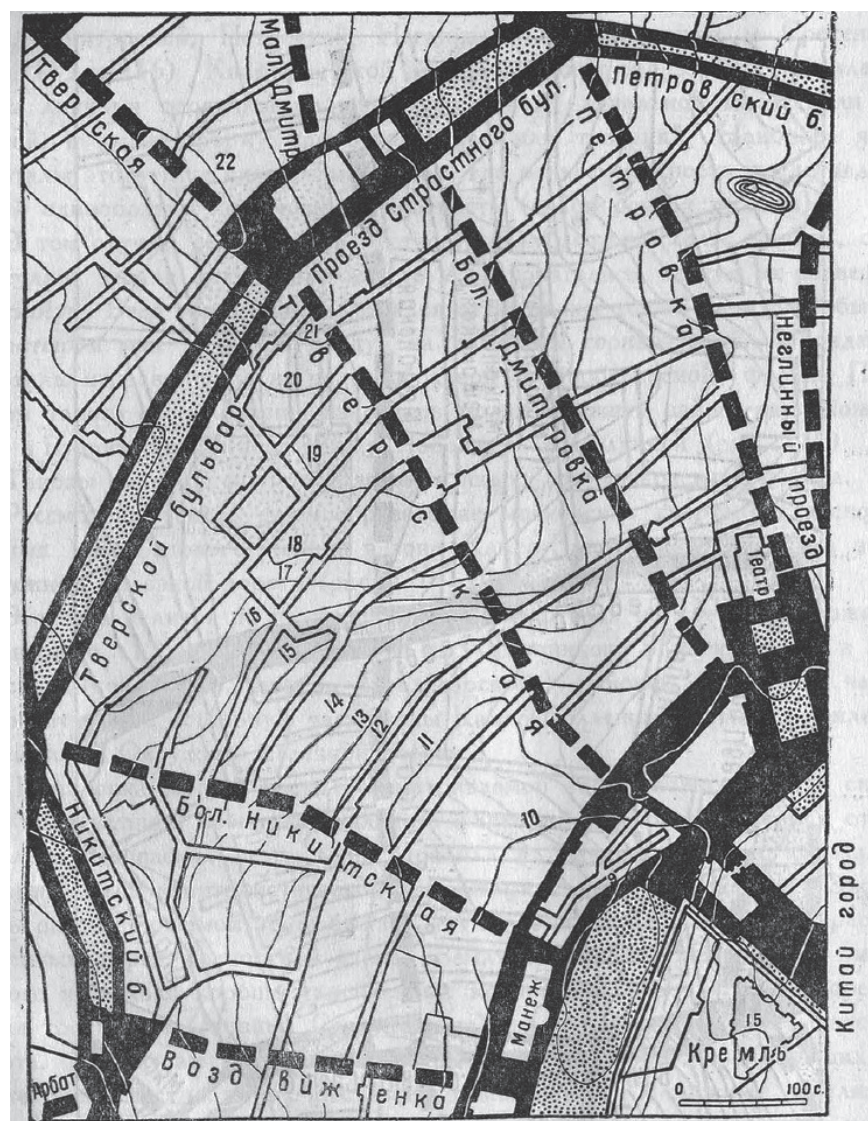

Рис. 7. Иллюстрация П.И. Гольденберга «Формообразование кварталов на московском плане» из книги «Планировка жилого квартала Москвы XVII, XVIII и XIX вв.». 1935 год (источник: [11, с. 165])
Первый предполагал включение в один блок помимо квартир предприятий культурно-бытового обслуживания, то есть частичное обобществление быта, второй - строительство жилых домов и предприятий культурно-бытового обслуживания в отдельных зданиях неподалеку. П.И. Гольденберг считал, что каждый из этих вариантов может быть применим при определённой системе планировки квартала - строчной или периметральной. Причём, к достоинствам последней он относил сохранение цельности внутриквартальной территории и возможность её озеленения при застройке квартала дифференцированным типом жилья. В целом же архитектор полагал, что для Москвы применим любой из этих типов застройки «в зависимости от конкретных условий и главным образом от архитектурных требований» [10, с. 34]. Однако требования архитектурного оформления магистралей Москвы и активная критика «унылой» строчной застройки, которую связывали с наследием группы Э. Мая, сделали выводы П.И. Гольденберга довольно спорными.

От работы П.И. Гольденберга в АКХ, куда он перешёл после увольнения из АПУ, окончательно отказавшись от проектной деятельности, не сохранилось практически никаких публикаций. В стенах академии он продолжил исследование проблем жилого квартала в составе бригады Н.А. Ладовского, в которую также входили Л.0 Гришпун, А.И. Каплун и И.А. Длугач ${ }^{14}$. Согласно сохранившимся документам работа называлась «Проблема соцреконструкции района Москвы» или «Социалистическая реконструкция московского жилого квартала» и предполагалась к изданию в виде книги. П.И. Гольденберг отвечал за исторический раздел работы, включавший изучение «истории развития квартала Москвы в 17, 18 и 19 веках» и кварталов современной Москвы, а также за ту часть методологического раздела, которая касалась определения «социально-бытовых условий организации квартала» и «строительных типов зданий». Прочие составляющие методологического раздела, а также весь проектировочный раздел должны были готовить остальные участники бригады. Однако никаких следов этой работы бригады Н.А. Ладовского выявить не удалось ${ }^{15}$. Выполненная П.И. Гольденбергом при участии брата историческая часть была издана в 1935 году отдельной книгой «Планировка жилого квартала Москвы XVII, XVIII и XIX вв.» [11]. Она стала важной вехой в творчестве архитектора - отправной точкой его интереса к истории Москвы и к изучению исторических планов столицы (рис. 6, 7).

Ко времени издания книги П.И. Гольденберг вновь работал в Отделе планировки Моссовета над проблемой проектирования жилого квартала, параллельно занимаясь историей планировочного развития Москвы ${ }^{16}$. И хотя по состоянию

14 Календарный план работы бригады Н.А. Ладовского (источник: РГАЭ. Ф. 185. 0п. 1. Д. 73. Л. 13 об. - 13).

${ }^{15}$ Материалов научно-исследовательской деятельности АКХ за первые годы ее существования практически не сохранилось.

${ }^{16}$ На эту тему в предвоенный период вышло три статьи П.И. Гольденберга: две о развитии города [12; 13] и одна с анализом планов старой Москвы [14]. 
здоровья он в итоге перешёл на работу во Всесоюзную академию архитектуры, период 1935-1940 годов стал для архитектора наиболее плодотворным периодом по части публикации его трудов.

Будучи признанным специалистом по проблеме проектирования жилого квартала, он писал рецензии на работы своих коллег, занимавшихся теми же вопросами. Две рецензии на работы Ю.Г. Круглякова [16] и Г.В. Шелейховского [15, с. 79] - были опубликованы. И не случайно именно статья П.И. Гольденберга о проблеме жилого квартала в новой Москве была помещена в журнале «Архитектура СССР», приуроченном к принятию постановления СНК СССР и ЦК ВКП(б) «0 генеральном плане реконструкции г. Москвы» [17]. И также вполне закономерно, что в другой статье, приуроченной к публикации «Правил о порядке застройки города Москвы», утверждённых в октябре 1935 года, П.И. Гольденберг был вынужден давать пояснения по некоторым весьма неконкретным установкам по проектированию жилых кварталов, зафиксированным в постановлении о Генеральном плане ${ }^{17}$ [18].

В 1936 году П.И. Гольденберг принял участие в дискуссии, в которой обсуждались проблемы архитектурной организации квартала, в первую очередь - принципы его застройки. К этому времени периметральная застройка, которая в 1932-1933 годах виделась многим самым простым и логичным решением в свете установок по архитектурному оформлению магистралей, стала подвергаться активной критике как по эстетическим, так и по многим иным соображениям. В одной из статей П.И. Гольденберг отмечал, что «чисто периметральная застройка не в состоянии обеспечить достижения заданных нам плотностей заселения кварталов», и, следовательно, «встаёт задача применения новой системы застройки, охватывающей единым смыслом внешнюю и внутреннюю застройку квартала» [19, с. 16]. При этом один из возможных путей решения этой проблемы, предлагавшийся М.Я. Гинзбургом в проекте нового района Нижнего Тагила, критиковался П.И. Гольденбергом за «бесквартальный» принцип планировки, за низкие показатели плотности населения и т.д., хотя работа в целом называлась «талантливой, но уникальной вещью» [20, с. 24] (рис. 8).

Всё многообразие проблем, с которыми сталкивались специалисты (не только архитекторы) при проектировании жилого квартала в то время, можно понять из отчётной статьи П.И. Гольденберга о Всесоюзной конференции по планировке жилого квартала, созванной Государственной санитарной инспекцией СССР и Научно-исследовательским институтом коммунальной санитарии и гигиены в декабре 1936 года [21]. На этой конференции обсуждались не только размещение предприятий культурно-бытового обслуживания, проблема внутриквартальных гаражей,

17 Например, такую: «застройку кварталов производить небольшим количеством крупных домов, расположенных друг от друга на некотором небольшом расстоянии для лучшего освещения и проветривания квартала». но вопросы шума, теплового и ветрового режима внутри квартала и ряд других крайне важных, но не столь очевидных проблем. Поэтому не должен вызывать удивления тот факт, что многие статьи П.И. Гольденберга второй половины 1930-х годов, в которых освещалась современная для тех лет практика проектирования кварталов, носили весьма критический характер и фиксировали те проблемы, с которыми сталкивались архитекторы, вынужденные единовременно следовать ряду весьма разнохарактерных требований эстетического, санитарно-гигиенического и функционального характера (рис. 9).

Опыт П.И. Гольденберга в сфере изучения жилых кварталов Москвы оказался востребован при подготовке картограмм разделов «Старая Москва» и «Жилой квартал» для альбома Изостата «Москва реконструируется» (1938) [22] (рис. 10). В 1939-1940 годах архитектором для Академии коммунального хозяйства была подготовлена рукопись «Жилой квартал. Нормы детального проектирования», судьбу которой проследить, к сожалению, не удалось ${ }^{18}$.

${ }^{18}$ Список основных трудов и изобретений П.И. Гольденберга // РГАЭ. Ф. 185. 0п. 1. Д. 230. Л. 1. Черновики рукописи сохранились среди бумаг архитектора (Жилой квартал. АКХ // РГАЭ. Ф. 185. 0п. 1. Д. З. Ч. 1. Л. 66-118).

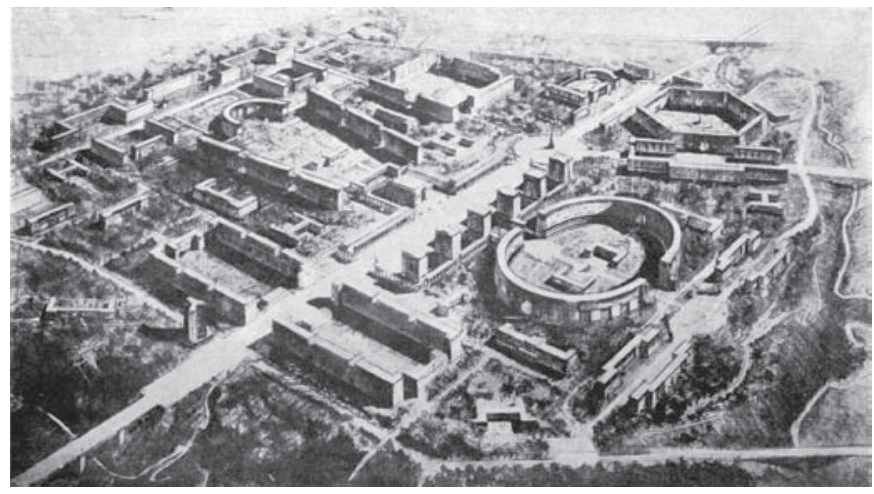

Рис. 8. Проект района «Красный камень» в Нижнем Тагиле. Архитектор М.Я. Гинзбург и др. 1936 год (источник: [20, с. 27])

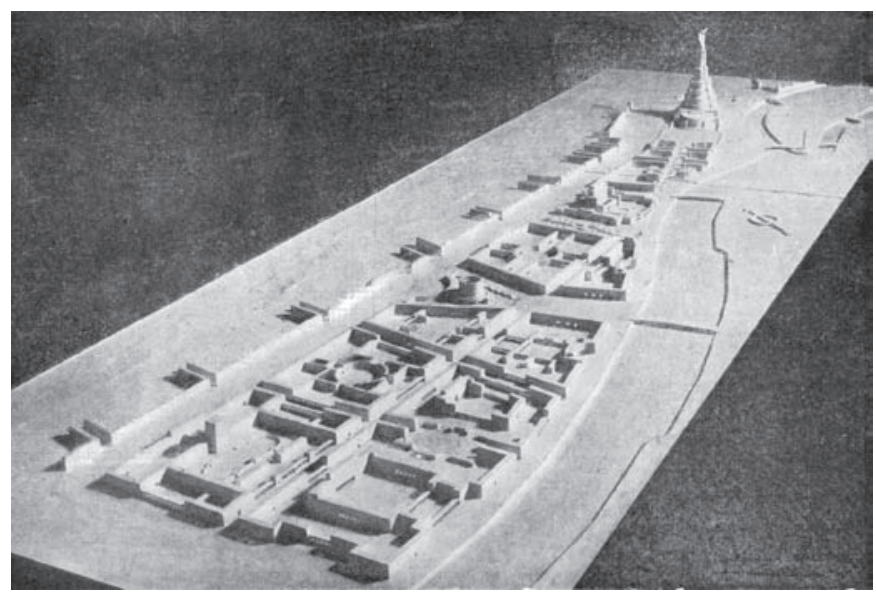

Рис. 9. Проект застройки территории, прилегающей к Двориу Советов в Москве. Архитектор Б.М. Иофан и др. 1936 год (источник: [20, с. 26]) 
И хотя сотрудник Академии архитектуры П.И. Гольденберг непосредственно проблемой квартала не занимался, он смог подготовить и издать книгу «Набережные Москвы» [23], а также принимал активное участие в подготовке первого советского учебника по градостроительству, работы над которым были прерваны войной [24].

19 июня 1944 года решением Учёного совета Академии архитектуры СССР П.И. Гольденбергу за работу «Нормальный профиль жилой улицы посёлка», подготовленную за годы войны, была присуждена учёная степень кандидата архитектурных наук ${ }^{19}$. Оппонентами на защите были А.П. Иваницкий и А.Е. Страментов ${ }^{20}$. Диссертацию планировалось издать в виде книги, но этим планам помешала разразившаяся после войны борьба с космополитизмом, которая весьма ощутимо сказалась на деятельности архитектора. Его последней крупной работой, опубликованной ещё до разгара этой кампании, стала научно-популярная книга «Старая Москва», приуроченная к юбилею города [25]. После 1953 года он принимал участие в больших работах Института градостроительства Академии архитектуры, однако с 1956 года отношения с руководством института у П.И. Гольденберга не складывались, и в 1961 году он уволился. После этого и вплоть до своей смерти в 1971 году он продолжал изучать историю развития Москвы, собирал весь доступный материал, в том числе о развитии и реконструкции города в 1920-е - 1930-е годы. К сожалению, он не оставил детальных воспоминаний о событиях, непосредственным свидетелем и участником которых был сам, но собранные им материалы позволяют совершенно иначе увидеть многие знаковые сюжеты из архитектурноградостроительной истории Москвы 1930-х годов.

Подводя итог, необходимо отметить, что творческий путь и труды Петра Исааковича Гольденберга безусловно заслуживают дальнейшего изучения. Представленные в настоящей статье материалы позволяют говорить о весомом вкладе архитектора в формирование принципов архитектурно-пространственной организации жилого квартала уже на первом этапе появления этой проблемы в начале 1930-х годов. На протяжении всего этого десятилетия П.И. Гольденберга входил в весьма узкий круг советских специалистов, которые пытались в условиях постоянно меняющихся установок и требований, с одной стороны, разработать нормативы проектирования жилых кварталах, а с другой - сформулировать архитектурно-градостроительные принципы их устройства. И сегодня труды этих специалистов, ранее никогда не становившиеся объектом историко-архитектурного исследования, позволяют существенно расширить наши знания о советском градостроительстве 1930-х годов.

${ }^{19}$ Выписка из протокола № 3 заседания Учёного совета Академии архитектуры Союза ССР от 19 июня 1944 года (источник: РГАЭ. Ф. 185. 0п. 1. Д. 226. Л. 1).

${ }^{20}$ Гольденберг П. Автобиография. 15 января 1937 г. [Дополнялась после 1942 г.] (источник: РГАЭ. Ф. 185. Оп. 1. Д. 226. Л. 9).

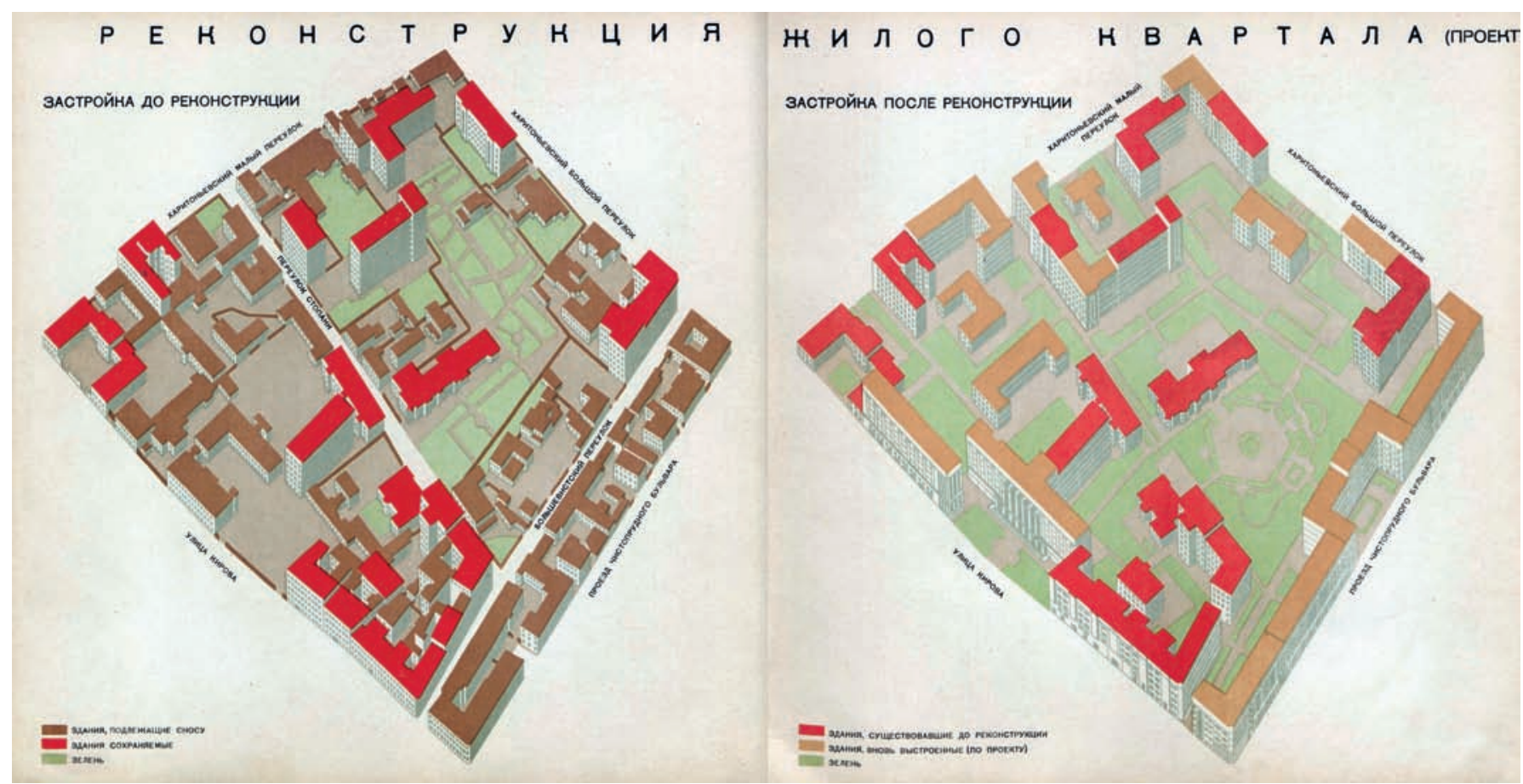

Рис. 10. Графическая схема «Реконструкция жилого квартала», подготовленная при участии П.И. Гольденберга для альбома «Москва реконструируется». 1935 год (источник: [22]) 


\section{Лuтература:}

1. Гарнюк, С.Д. Московская власть. Советские органы управления. Март 1917 - октябрь 1993 : справочник / отв. редактор М.М. Горинов. - М. : Издательство Главного архивного управления города Москвы, 2011.

2. Болдырев, С. Москва. Вопросы перепланировки / С. Болдырев, П. Гольденберг, В. Долганов // Советская архитектура. - 1931. - № 4. - С. 32-37.

3. Гольденберг, П. Капитальное или облегчённое стандартное строительство / П. Гольденберг, В. Долганов // Строительство Москвы. - 1931. - № 5. - С. 11-16.

4. Гольденберг, П. Жилой комбинат / П. Гольденберг, В. Долганов // Коммунальное хозяйство. - 1931. - № 13-14. - С. $21-27$.

5. Гольденберг П., Долганов В. Проблема жилого квартала / П. Гольденберг, В. Долганов; предисловие В. Н. Семёнова. - М., Л. : Техника управления, 1931.

6. Старостенко, Ю.Д. Книга П.И. Гольденберга и В.И. Долганова «Проблема жилого квартала» (1931) и её роль в поиске путей преобразования Москвы в начале 1930-х годов / Ю.Д Старостенко // Наука, образование и экспериментальное проектирование в МАРХИ : Тезисы докладов международной научно-практической конференции профессорско-преподавательского состава, молодых ученых и студентов, 8-12 апреля 2019 г. : в 2-х тт. Том 1. - М. : МАРХИ, 2019. - С. 219-220.

7. Луни, Л.Б. Перспективы строительства Центрального Парка культуры и отдыха / Л.Б. Лунц // Советская архитектура. - 1932. - № 1. - С. 35-52.

8. Гольденберг, П. Задачи социалистической реконструкции Москвы (Проекты перепланировки Москвы) / П. Гольденберг, Б. Гольденберг // Советская архитектура. - 1933. - № 1. - С. 14-25.

9. Старостенко, Ю.Д. История проведения конкурса на проект планировки Москвы 1932 года в свете новых архивных материалов / Ю.Д Старостенко // Academia. Архитектура и строительство. - 2019. - № 4. - С. 32-41.

10. Гольденберг, П. Строчная или периметральная застройка квартала / П. Гольденберг // Строительство Москвы. - 1933. - № 1. - С. 31-34.

11. Гольденберг, П. Планировка жилого квартала Москвы XVII, XVIII и XIX вв. / П. Гольденберг, Б. Гольденберг; под редакцией Л.М. Перчика и И.Е. Бондаренко. - М., Л. : Главная редакция строительной литературы, 1935.

12. Гольденберг, П.И. Как росла старая Москва / П.И. Гольденберг, Б.И. Гольденберг // Архитектура СССР. - 1935. - № 10-11. - С. 94-104.

13. Гольденберг П. Как росла Москва / П. Гольденберг // Строительство Москвы. - 1936. - № 18. - С. 25-28.

14. Гольденберг, П. Планы старой Москвы / П. Гольденберг // Архитектура СССР. - 1940. - № 4. - С. 68-70.

15. Гольденберг, П. [Рецензия на книгу Ю. Круглякова «Реконструкция жилых кварталов»] / П. Гольденберг // Архитектура СССР. - 1934. - № 8.

16. Гольденберг, П. [Рецензия на статью Г.В. Шелейховского «Жилой квартал как низовое звено города, его элементы и нормативы»] / П. Гольденберг // Планировка и строительство городов. - 1935. - № 7. - С. 48-49.

17. Гольденберг, П.И. Квартал в новой Москве / П. Гольденберг // Архитектура СССР. - 1935. - № 10-11. - С. 59-63.

18. Гольденберг, П.И. Жилой квартал Москвы / П.И. Гольденберг // Планировка и строительство городов. - 1935. - № 10. - С. 5-7.

19. Гольденберг, П. Возможна ли чисто периметральная застройка московских кварталов / П. Гольденберг // Строительство Москвы. - 1936. - № 20. - С. 14-16.

20. Гольденберг, П. Опыт проектирования новых жилых кварталов / П. Гольденберг // Архитектура СССР. - 1936. - № 9. - С. 24-28.

21. Гольденберг, П. Планировка жилого квартала / П. Гольденберг // Архитектурная газета. - 4 января 1937. - № 1 (145). - С. 2.

22. Москва реконструируется : альбом диаграмм, топосхем и фотографий по реконструкции гор. Москвы / редакторсоставитель И.П. Иваницкий; текст В. Шкловский. - М. : Институт Изостат, 1938.

23. Гольденберг, П.И. Набережные Москвы: архитектура и конструкция / П.И. Гольденберг, Л.С. Аксельрод. - М. : Издательство Академии архитектуры СССР, 1940.

24. Старостенко, Ю.Д. Первый советский учебник по градостроительству: попытка обобщения накопленного опыта во второй половине 1930-х гг. / Ю.Д. Старостенко // Региональные архитектурно-художественные школы. - 2019. - № 1. - С. 200-204.

25. Гольденберг, П.И. Старая Москва / П.И. Гольденберг. М. : Издательство Академии архитектуры СССР, 1947.

\section{References}

1. GarnyukS.D. Moskovskaya vlast'. Sovetskie organy upravleniya. Mart 1917 - oktyabr' 1993 : spravochnik [Moscow administration. Soviet government bodies. March 1917 - October 1993 : directory], M.M. Gorinov (ed.). Moscow, Publishing House of the Main Archival Administration of the City of Moscow Publ., 2011. (In Russ.)

2. Boldyrev S., Goldenberg P., Dolganov V. Moskva. Voprosy pereplanirovki [Moscow. The issues of redevelopment]. In: Sovetskaya arkhitektura [Soviet architecture], 1931, no. 4, pp. 32-37. (In Russ.)

3. Goldenberg P., Dolganov V. Kapital'noe ili oblegchennoe standartnoe stroitel'stvo [Capital or lightweight standard construction]. In: Stroitelstvo Moskvy [Construction of Moscow], 1931, no. 5, pp. 11-16. (In Russ.)

4. Goldenberg P., Dolganov V. Zhiloi kombinat [Residential complex]. In: Kommunalnoe khozyajstvo [Communal service], 1931, no. 13-14, pp. 21-27. (In Russ.)

5. Goldenberg P., Dolganov V. Problema zhilogo kvartala [The problem of the residential quarter]. Foreword by V.N. Semenov. Moscow, Leningrad, Tekhnika upravleniya Publ., 1931.

6. Starostenko Y.D. Kniga P.I. Gol'denberga i V.I. Dolganova «Problema zhilogo kvartala» (1931) i ee rol' v poiske putei preobrazovaniya Moskvy v nachale 1930-kh godov [The book by P.I. Goldenberg and V.I. Dolganov "The Problem of the 
Residential quarter" (1931) and its role in the search for ways to transform Moscow in the early 1930s.]. In: Nauka, obrazovanie i eksperimental'noe proektirovanie v MARKHI: Tezisy dokladov mezhdunarodnoi nauchno-prakticheskoi konferentsii professorsko-prepodavatel'skogo sostava, molodykh uchenykh i studentov, 8-12 aprelya $2019 \mathrm{~g}$. [Science, education and experimental design in MARKHI. Abstracts of reports of the international scientific and practical conference of teaching staff, young scientists and students, April 8-12, 2019], in 2 volumes, vol. 1. Moscow, MARKHI Publ., 2019, pp. 219-220. (In Russ.)

7. Lunts L.B. Perspektivy stroitel'stva Tsentral'nogo Parka kul'tury i otdykha [Prospects for the construction of the Central Park of culture and recreation]. In: Sovetskaya arkhitektura [Soviet architecture], 1932, no. 1, pp. 35-52. (In Russ.)

8. Goldenberg P., Goldenberg B. Zadachi sotsialisticheskoi rekonstruktsii Moskvy (Proekty pereplanirovki Moskvy) [Tasks of the socialist reconstruction of Moscow (Moscow redevelopment Projects)]. In: Sovetskaya arkhitektura [Soviet architecture], 1933, no. 1, pp. 14-25. (In Russ.)

9. Starostenko Y.D. Istoriya provedeniya konkursa na proekt planirovki Moskvy 1932 goda v svete novykh arkhivnykh materialov [History of the Competition for the Moscow planning project of 1932 in connection with finding new archival materials]. In: Academia. Arkhitektura i stroitelstvo [Academia. Architecture and construction], 2019, no. 4, pp. 32-41. (In Russ., abstr. in Engl.)

10. Goldenberg P. Strochnaya ili perimetral'naya zastroika kvartala [Line building or ribbon building of the quarter]. In: Stroitelstvo Moskvy [Construction of Moscow], 1933, no. 1, pp. 31-34. (In Russ.)

11. Goldenberg P., Goldenberg B. Planirovka zhilogo kvartala Moskvy XVII, XVIII i XIX vv. [Planning of the residential quarter of Moscow of the XVII, XVIII and XIX centuries], L.M. Perchik and I.E. Bondarenko (eds.). Moscow, Leningrad, Main edition of construction literature Publ., 1935. (In Russ.)

12. Goldenberg P.I., Goldenberg B.I. Kak rosla staraya Moskva [How old Moscow grew]. In: Arkhitektura SSSR [Architecture of the USSR], 1935, no. 10-11, pp. 94-104. (In Russ.)

13. Goldenberg P. Kak rosla Moskva [How Moscow grew]. In: Stroitelstvo Moskvy [Construction of Moscow], 1936, no. 18, pp. 25-28. (In Russ.)

14. Goldenberg P. Plany staroi Moskvy [Plans of old Moscow]. In: Arkhitektura SSSR [Architecture of the USSR], 1940, no. № 4, pp. 68-70. (In Russ.)

15. Goldenberg P. Retsenziya na knigu Y. Kruglyakova "Rekonstruktsiya zhilykh kvartalov" [Review of the book by
Yu. Kruglyakov "Reconstruction of residential quarters"]. In: Arkhitektura SSSR [Architecture of the USSR], 1934, no. 8, p. 79. (In Russ.)

16. Goldenberg P. Retsenziya na stat'yu G.V. Sheleikhovskogo «Zhiloi kvartal kak nizovoe zveno goroda, ego elementy $i$ normativy» [Review of the article by G. V. Sheleykhovsky "Residential quarter as a lower level of the city, its elements and standards"]. In: Planirovka i stroitelstvo gorodov [Planning and construction of cities], 1935, no. 7, pp. 48-49. (In Russ.)

17. Goldenberg P.I. Kvartal v novoi Moskve [Quarter in new Moscow]. In: Arkhitektura SSSR [Architecture of the USSR], 1935, no. 10-11, pp. 59-63. (In Russ.)

18. Goldenberg P.I. Zhiloi kvartal Moskvy [Residential quarter of Moscow]. In: Planirovka i stroitelstvo gorodov [Planning and construction of cities], 1935, no. 10, pp. 5-7. (In Russ.)

19. Goldenberg P. Vozmozhna li chisto perimetral'naya zastroika moskovskikh kvartalov [Is it possible to build purely ribbon building in Moscow's quarters]. In: Stroitelstvo Moskvy [Construction of Moscow], 1936, no. 20, pp. 14-16. (In Russ.)

20. Goldenberg P. Opyt proektirovaniya novykh zhilykh kvartalov [Experience of designing new residential quarters]. In: Arkhitektura SSSR [Architecture of the USSR], 1936, no. 9, pp. 24-28. (In Russ.)

21. Goldenberg P. Planirovka zhilogo kvartala [Planning of a residential quarter]. In: Arkhitekturnaya gazeta [Architectural newspaper], 1937, no. 1 (145), pp. 2. (In Russ.)

22. Moskva rekonstruiruetsya : al'bom diagramm, toposkhem i fotografii po rekonstruktsii gor. Moskvy [Moscow is under reconstruction. Album of diagrams, topographic diagrams and photographs on the reconstruction of the city of Moscow]. Eds. I.P. Ivanitskij, text V. Shklovskij. Moscow: Institut Izostat Publ., 1938. (In Russ.)

23. Goldenberg P.I., Akselrod L.S. Naberezhnye Moskvy: arkhitektura i konstruktsiya. [Embankments of Moscow. Architecture and construction]. Moscow, Akademii arkhitektury SSSR Publ., 1940. (In Russ.)

24. Starostenko Y.D. Pervyi sovetskii uchebnik po gradostroitel'stvu: popytka obobshcheniya nakoplennogo opyta vo vtoroi polovine 1930-kh gg. [First soviet textbook on town planning: an attempt to generalize the accumulated experience in the second half of the 1930s.]. In: Regionalnye arkhitekturnokhudozhestvennye shkoly [Regional architectural and art schools], 2019, no. 1, pp. 200-204. (In Russ.)

25. Goldenberg P.I. Staraya Moskva [Old Moscow]. Moscow, Izdatelstvo Akademii arkhitektury SSSR Publ., 1947. (In Russ.)

Старостенко Юлия Дмитриевна (Москва). Кандидат архитектуры. Старший научный сотрудник Научно-исследовательского института теории и истории архитектуры и градостроительства (филиал ФГБУ «ЦНИИП Минстроя России») (111024, Москва, ул. Душинская, 9. НИИтИАГ). Эл.почта: ystarostenko@yandex.ru.

Starostenko Yulia D.(Moscow). Candidate of Architecture. Senior researcher at the Research Institute of Theory and History of Architecture and Urban Planning (9 Dushinskaya st, Moscow, 111024. NIITIAG), branch of the Central Institute for Research and Design of the Ministry of Construction and Housing and Communal Services of the Russian Federation (TsNIIP). E-mail: ystarostenko@yandex.ru. 